Article

\title{
Adsorption of Thiophenic Compounds from Model Diesel Fuel Using Copper and Nickel Impregnated Activated Carbons
}

\author{
Elham S. Moosavi ${ }^{1}$, Seyed A. Dastgheib ${ }^{2}$ and Ramin Karimzadeh ${ }^{1, *}$
}

1 Chemical Engineering Faculty, Tarbiat Modares University, Post Office Box 14155-4838, Tehran, Iran; E-Mail: moosavi_el@yahoo.com

2 Illinois State Geological Survey, Prairie Research Institute, University of Illinois, 615 E. Peabody Drive, Champaign, IL 61820, USA; E-Mail: seyed@illinois.edu

* Author to whom correspondence should be addressed; E-Mail: ramin@modares.ac.ir; Tel.: +98-21-82883315; Fax: +98-21-88006544.

Received: 18 July 2012; in revised form: 13 September 2012 / Accepted: 20 September 2012 / Published: 23 October 2012

\begin{abstract}
Adsorption of sulfur compoundsby porous materials is an effective way to produce cleaner diesel fuel.In this study, adsorption of refractory thiophenic sulfur compounds, i.e., benzothiophene (BT), dibenzothiophene (DBT), and 4,6-dimethyldibenzothiophene (4,6-DMDBT) in single-solute systems from $n$-hexane solutions onto metal-impregnated activated carbons was investigated. A hydrogen-treated activated carbon fiber was selectively loaded with $\mathrm{Ni}, \mathrm{NiO}, \mathrm{Cu}, \mathrm{Cu}_{2} \mathrm{O}$, and $\mathrm{CuO}$ species to systematically assess the impact of each metal species on the adsorption of thiophenic compounds (TC). Metal-loaded adsorbents had the same total metal contents and similar microporosities, but contained different types of copper or nickel species. All metal-loaded adsorbents showed enhanced adsorption of tested TC. $\mathrm{Cu}_{2} \mathrm{O}$ - or NiO-loaded adsorbents exhibited the highest uptakes, due to more specific interactions between $\mathrm{Cu}^{+}$or $\mathrm{Ni}^{2+}$ species and $\mathrm{TC}$ molecules. The theoretical monolyer coverage of TC on the exposed $\mathrm{Cu}^{+}$sites was estimated and compared with that calculated from the experimental data. Results suggested catalytic conversion of TC molecules to other compounds on the $\mathrm{Cu}^{+}$sites, followed by adsorption of reaction products onto the carbon surface or multilayer accumulation of TC molecules on the $\mathrm{Cu}^{+}$sites. TC adsorption uptake of the majority of adsorbents followed the order of: 4,6-DMDBT > DBT > BT due to higher intensity of specific and non-specific interactions of larger TC molecules with adsorbents.
\end{abstract}

Keywords: adsorption; activated carbon; thiophenic compound; impregnation; copper; nickel 


\section{Introduction}

Sulfur compounds in fossil fuels oxidize to $\mathrm{SO}_{\mathrm{x}}$ species and cause different air pollution problems. The majority of sulfur-containing hydrocarbons in liquid fuels are converted to sulfur-free compounds and $\mathrm{H}_{2} \mathrm{~S}$ by catalytic hydrodesulphurization (HDS) reactions during the fuel processing. Although the HDS process is the best known technology for desulfurization of liquid fuels, it cannot efficiently remove thiophenic compounds (TC) including dibenzothiophene (DBT), 4,6-dimethyldibenzothiophene (4,6-DMDBT), and benzothiophene (BT) to meet the new environmental regulations of 15-30 ppm sulfur in the processed fuels [1-5]. Reactivity studies of BT, DBT and their alkylated homologues in HDS reactions over $\mathrm{Co}, \mathrm{Mo} / \mathrm{Al}_{2} \mathrm{O}_{3}, \mathrm{Ni}, \mathrm{Mo} / \mathrm{Al}_{2} \mathrm{O}_{3}$ and sulfide $\mathrm{Co}, \mathrm{Mo} / \gamma-\mathrm{Al}_{2} \mathrm{O}_{3}$ catalysts indicate that the alkyl group substituents, especially in positions subject to steric hindrance effects (e.g., 4 and 6 in the 4,6-DMDBT molecule) significantly reduce the reactivity of TC in HDS reactions [2-4].

Several polishing processes such as reactive adsorption, non-destructive adsorption, extraction, and oxidative desulphurization are suggested to supplement the conventional HDS process and produce ultra-clean fuels [6,7]. Adsorption processes are some of the most economically attractive methods because of the straightforward operating conditions and availability of inexpensive and re-generable adsorbents including zeolites, metal-based adsorbents, silica, alumina, and activated carbon [8-19]. Adsorbents are modified by different treatment methods, including metal impregnation and oxidation, to enhance their affinities for the removal of TC from liquid fuels [20-30]. Zeolites, alumina, silica and activated carbon are impregnated with various transition metals such as $\mathrm{Cu} ; \mathrm{Ni} ; \mathrm{Ag} ; \mathrm{Zn}$; $\mathrm{Fe}$; and $\mathrm{Pd}$, to prepare adsorbents with higher capacities for TC removal from commercial and model fuels [8,11,14,16,20-26]. Enhanced TC adsorption of several metal-impregnated adsorbents is explained by specific interactions (i.e., chemical interactions) between the metals and thiophenic molecules [8,12,14,20,21,31-33]. Adsorbent pore geometry is also an important factor in TC adsorption. For example, Xiao et al. reported that a large fraction of $\mathrm{NaY}$ zeolite cylindrical pores are not accessible to the DBT molecules [22].

Activated carbons due to their low cost, high surface area, thermal and chemical stability under anoxic conditions, receptivity for modification, and high affinity toward adsorption of aromatic and refractory sulfur compounds have been extensively studied for the removal of TC from different fuels [27]. Activated carbon pores have a slit shape geometry that is more suitable for adsorbing planar aromatic compounds (e.g., TC), compared to the cylindrical zeolite pores that are more suitable for the adsorption of non-planar molecules [34]. Various researchers have explored adsorption of BT, DBT, and 4,6-DMDBT from commercial or model fuels by different types of activated carbons, including oxidized or metal-impregnated adsorbents [20,22,23,25,26,30,35,36]. The overall understanding in the current literature is that TC adsorption by activated carbon is enhanced both by carbon microporosity and favorable surface chemistry [26,28,31]. TC adsorption is significantly increased by enhanced overlapping potential effects of narrow carbon ultra-micropores $(<7 \AA)$ and specific interactions of surface oxygen and sulfur functionalities and metal species with the TC molecules. Several studies investigated the impact of impregnation by $\mathrm{Na}, \mathrm{Co}, \mathrm{Ag}, \mathrm{Cu}, \mathrm{Co}, \mathrm{Ni}, \mathrm{Fe}$, and $\mathrm{Zn}$ on the $\mathrm{TC}$ adsorption of activated carbons [20-26,32,33]. It is reported that TC adsorption uptake by activated carbon can be 
particularly enhanced by impregnation with copper and nickel, including $\mathrm{Cu}_{2} \mathrm{O}$ and $\mathrm{NiO}$ species [20-22,24-26,37].

The main objective of this research was to investigate and compare the adsorption of BT, DBT, and 4,6-DMDBT from $n$-hexane (as a model fuel) in single-solute systems by activated carbons selectively impregnated with $\mathrm{Ni}, \mathrm{NiO}, \mathrm{Cu}, \mathrm{Cu}_{2} \mathrm{O}$, or $\mathrm{CuO}$. The main contribution of this study is to systematically assess the impact of different copper or nickel oxidation states (i.e., $\mathrm{Cu}^{2+}, \mathrm{Cu}^{1+}, \mathrm{Cu}^{0}, \mathrm{Ni}^{2+}$, and $\mathrm{Ni}^{0}$ ) on the TC adsorption onto the copper- or nickel-impregnated activated carbon. Although other studies have reported that both nickel and copper enhance TC uptake onto activated carbon, this study quantifies the importance of different individual metal species on the TC adsorption. A specific approach of this work is to subject the adsorbents (prior to the metal impregnation) to a high temperature hydrogen reduction treatment to remove acidic oxygen functionalities that are suggested to increase TC adsorption onto activated carbons [30,35,36] therefore their impact can be ignored. A microporous activated carbon fiber (ACF) was first subjected to high temperature hydrogen treatment then selectively impregnated with $\mathrm{Ni}$ or $\mathrm{Cu}$ species. Prepared adsorbents have similar microporosites, therefore their enhanced TC uptake can be attributed to the specific interaction effects with different loaded metal species. The effect of different copper or nickel species (with different oxidation states) on the enhancement of TC uptake is quantified from the adsorption isotherms. A mesoporous activated carbon, that has a micropore volume similar to the ACF but contains a considerable mesopore volume, is also prepared and impregnated with selected copper species to further investigate the impact of carbon mesoporosity on the TC removal with and without the copper impregnation.

\section{Methodology}

\subsection{Material Preparation}

A polyacrylonitryl-based commercial activated carbon fiber (ACF) (Beijing Evergrow Resources, Beijing, China) and a mesoporous activated carbon (AC) were used in this study. $\mathrm{Cu}\left(\mathrm{NO}_{3}\right)_{2} \cdot 3 \mathrm{H}_{2} \mathrm{O}$, $\mathrm{Ni}\left(\mathrm{NO}_{3}\right)_{2} \cdot 6 \mathrm{H}_{2} \mathrm{O}$, BT, DBT (all with $>99 \%$ purity) were purchased from Merck (Hohenbrunn, Germany). 4,6-DMDBT (97\% purity) and $n$-hexane (99.9\% purity) were obtained from Jinan Haohua Industry (Jinan, China), and Dr. Mojalali Company (Tehran, Iran), respectively.

AC samples were prepared from palm seeds in our laboratory by $\mathrm{ZnCl}_{2}$ impregnation. At first the palm seeds were dried in a vacuum oven at $100{ }^{\circ} \mathrm{C}$ for $12 \mathrm{~h}$, then crushed and sieved to a uniform size of $0.4-1 \mathrm{~mm}$. Subsequently, $\mathrm{ZnCl}_{2}$ was added to seeds. The weight ratio of $\mathrm{ZnCl}_{2}$-to seed was considered 2. $10 \mathrm{~mL}$ deionized water was added to this mixture which was then dehydrated at $110{ }^{\circ} \mathrm{C}$ overnight. The next step is activation in $\mathrm{CO}_{2}$ at $800{ }^{\circ} \mathrm{C}$ for $1.5 \mathrm{~h}$. After extensive washing with $1 \mathrm{~N} \mathrm{HCl}$ solution and water, and finally drying at $110{ }^{\circ} \mathrm{C}$ the mesoporous activated carbon (AC) sample is obtained [38]. As-received ACF and prepared AC samples were heat-treated under a hydrogen atmosphere in a quartz tube for $3 \mathrm{~h}$ at $900{ }^{\circ} \mathrm{C}$. Hydrogen-treated samples are labeled as ACFH and ACH.

$\mathrm{ACFH}$ and $\mathrm{ACH}$ were impregnated with copper or nickel by the incipient wetness method [28]. Carbons were loaded with $10 \%(\mathrm{w} / \mathrm{w})$ metal using $\mathrm{Cu}\left(\mathrm{NO}_{3}\right)_{2} \cdot 3 \mathrm{H}_{2} \mathrm{O}$ or $\mathrm{Ni}\left(\mathrm{NO}_{3}\right)_{2} \cdot 6 \mathrm{H}_{2} \mathrm{O}$ solutions. Impregnated samples were first left at the ambient conditions for $24 \mathrm{~h}$, then dried in a vacuum oven at $120{ }^{\circ} \mathrm{C}$ for $12 \mathrm{~h}$. Preparation steps and sample identification codes of different carbon adsorbents, 
loaded with different copper or nickel species, are shown in Table 1. Heat treatment conditions are selected based on the literature information that will be further discussed in Section 3. The different treatment steps and sample identification codes are listed in Table 1.

Table 1. Preparation steps of carbon samples impregnated with copper or nickel species.

\begin{tabular}{cccc}
\hline $\begin{array}{c}\text { Carbon } \\
\text { Sample }\end{array}$ & $\begin{array}{c}\text { Step 1: Heat treatment } \\
\left(\mathbf{9 0 0}{ }^{\circ} \mathbf{C} / \mathbf{H}_{\mathbf{2}}\right)\end{array}$ & $\begin{array}{c}\text { Step 2: Metal impregnation } \\
\text { (incipient wetness) }\end{array}$ & $\begin{array}{c}\text { Step 3: Heat } \\
\text { treatment }\end{array}$ \\
\hline $\mathrm{ACFH}$ & $\sqrt{ }$ & - & - \\
$\mathrm{ACFH}-\mathrm{Cu}^{2+}$ & $\sqrt{ }$ & $\mathrm{Cu}\left(\mathrm{NO}_{3}\right)_{2}$ & $400^{\circ} \mathrm{C} / \mathrm{N}_{2}$ \\
$\mathrm{ACFH}-\mathrm{Cu}^{+}$ & $\sqrt{ }$ & $\mathrm{Cu}\left(\mathrm{NO}_{3}\right)_{2}$ & $530^{\circ} \mathrm{C} / \mathrm{N}_{2}$ \\
$\mathrm{ACFH}-\mathrm{Cu}^{0}$ & $\sqrt{ }$ & $\mathrm{Cu}\left(\mathrm{NO}_{3}\right)_{2}$ & $800^{\circ} \mathrm{C} / \mathrm{N}_{2}$ \\
$\mathrm{ACFH}-\mathrm{Ni}^{2+}$ & $\sqrt{ }$ & $\mathrm{Ni}\left(\mathrm{NO}_{3}\right)_{2}$ & $550^{\circ} \mathrm{C} / \mathrm{N}_{2}$ \\
$\mathrm{ACFH}-\mathrm{Ni}^{0}$ & $\sqrt{ }$ & $\mathrm{Ni}\left(\mathrm{NO}_{3}\right)_{2}$ & $800^{\circ} \mathrm{C} / \mathrm{H}_{2}$ \\
$\mathrm{ACH}$ & $\sqrt{ }$ & - & - \\
$\mathrm{ACH}-\mathrm{Cu}^{+}$ & $\sqrt{ }$ & $\mathrm{Cu}\left(\mathrm{NO}_{3}\right)_{2}$ & $530^{\circ} \mathrm{C} / \mathrm{N}_{2}$ \\
\hline
\end{tabular}

\subsection{Characterization}

Crystalline nickel and copper species in activated carbons were identified by powder X-ray diffraction (XRD, STOE diffractometer) using $\mathrm{Cu} k \alpha$ radiation $(\lambda=0.15406 \mathrm{~nm})$ at $40 \mathrm{kV}$ and $30 \mathrm{~mA}$. The XRD data were recorded for $2 \theta$ values between $10^{\circ}$ and $90^{\circ}$ with an interval of $0.02^{\circ}$. The crystalline phases were identified by comparison with the reference data from the International Center for Diffraction Data (ICDD) database.

Total nickel or copper content of samples (after acid digestion) was measured by atomic absorption spectroscopy (AA-IES, Varian AA 240).Acidic surface oxygen groups of ACFH sample were quantified by the Boehm titration method by using $0.1 \mathrm{~N}$ sodium bicarbonate, sodium carbonate, and sodium hydroxide solutions [39].

Surface area and pore size distribution of carbon products were determined from adsorption isotherms of nitrogen from relative pressure $\left(\mathrm{P} / \mathrm{P}_{0}\right)$ of $10^{-6}$ to 1 at $77 \mathrm{~K}$ using a Micromeritics ASAP instrument. Samples were degassed in vacuum for $5 \mathrm{~h}$ at $180{ }^{\circ} \mathrm{C}$ prior to nitrogen adsorption. Surface area $\left(\mathrm{S}_{\mathrm{BET}}\right)$ was calculated from the linear range of the Brauner-Emmett-Teller (BET) equation in the relative pressure of 0.01 to 0.1 . Micropore volume $\left(\mathrm{V}_{\text {micro,DR }}\right)$ was calculated from the Dubinin-Radushkevich (DR) equation in the relative pressure range of $10^{-5}$ to $10^{-1}$. Total meso- and macropore volume $\left(\mathrm{V}_{\text {meso+macro}}\right)$ was calculated by subtracting the estimated micropore volume from the total volume.

Pore size (volume) distribution was determined from nitrogen isotherms employing the Micromeritics' Density Functional Theory (DFT) software using a graphite model with slit shape geometry and considering a low degree of regularization or data smoothing $(\lambda=0.005)$. Total pore volume $\left(\mathrm{V}_{\text {total }}\right)$ was calculated from the adsorbed volume of nitrogen near the saturation point $\left(\mathrm{P} / \mathrm{P}_{0}=0.98\right)$.

Surface area and dispersion of $\mathrm{Cu}^{+}$species on the impregnated carbon samples were determined from $\mathrm{CO}$ adsorption isotherms in the $1-450 \mathrm{mmHg} \mathrm{CO}$ pressure range at $35{ }^{\circ} \mathrm{C}$. Samples were evacuated under a high vacuum at $200{ }^{\circ} \mathrm{C}$ for $3 \mathrm{~h}$, then $350{ }^{\circ} \mathrm{C}$ for $0.5 \mathrm{~h}$, and finally cooled to $35^{\circ} \mathrm{C}$ prior to the $\mathrm{CO}$ adsorption experiments. 
Concentrations of BT, DBT, or 4,6-DMDBT in $n$-hexane were determined using a UV spectrophotometer instrument (Optizen $3220 \mathrm{UV}$ ) at 297, 325 or $284 \mathrm{~nm}$ wavelengths.

Selected DBT solutions after reaching the equilibrium were analyzed with a gas chromatography (GC) instrument (3420A Beifen), using a DB-5 column and a flame ionization detector (FID), to detect any possible degradation products of DBT that might be produced during the adsorption experiments. The column temperature was increased from 100 to $280{ }^{\circ} \mathrm{C}$ with the rate of $6{ }^{\circ} \mathrm{C} / \mathrm{min}$ and held at $280{ }^{\circ} \mathrm{C}$ for $10 \mathrm{~min}$. The injector temperature was $250^{\circ} \mathrm{C}$, and the detector temperature was maintained at $300{ }^{\circ} \mathrm{C}[40]$.

\subsection{Adsorption Isotherms}

Adsorption isotherm experiments of TC were carried out at room temperature using capped bottles containing $5 \mathrm{~mL}$ single-solute solutions and $0.05 \mathrm{~g}$ of activated carbon that were equilibrated for $8 \mathrm{~h}$. Each solution contained only one TC (i.e., DBT, or BT, or 4,6-DMDBT) dissolved in $n$-hexane. Initial concentrations of TC solutions were $330,462,660,990$, and $1,320 \mathrm{mg} / \mathrm{L}$ of TC. Kinetic tests have been done to determine the equilibrium time of BT, DBT and 4,6-DMDBT adsorption. For these experiments the ACFH sample was used as adsorbent because this has a microporous structure with about $\sim 100 \%$ micropore (pore with size less than $2 \mathrm{~nm}$ ) volume. Therefore this sample was expected to require the longest equilibration time among other samples [12,38]. Blank samples and random replicates were included in the experimental matrix for quality control and determination of data reproducibility. The average relative standard deviation of isotherm for different random replicate points was less than $10 \%$.

Concentrations of TC in filtered blank and equilibrated solutions were determined by UV spectroscopy. TC uptake was calculated from the equation: $\mathrm{q}_{\mathrm{e}}=\mathrm{V}\left(\mathrm{C}_{0}-\mathrm{C}_{\mathrm{e}}\right) / \mathrm{m}$, where $\mathrm{q}_{\mathrm{e}}$ is the adsorbed amount (mg sulfur/g adsorbent), $\mathrm{V}$ is the volume of solution (L), $\mathrm{C}_{0}$ and $\mathrm{C}_{\mathrm{e}}$ are initial and equilibrium concentrations ( $\mathrm{mg}$ sulfur/L), and $\mathrm{m}$ is the mass of adsorbent $(\mathrm{g})$.

\section{Results and Discussion}

\subsection{Adsorbent Preparation and Characterization}

\subsubsection{Adsorbent Preparation}

ACFH sample was prepared by hydrogen treatment of ACF at $900{ }^{\circ} \mathrm{C}$ for $3 \mathrm{~h}$ to remove the majority of surface oxygen functionalities and minimize the potential impact of these groups on the TC adsorption. A mesoporous activated carbon was prepared from palm seeds and subjected to the high temperature hydrogen treatment $(\mathrm{ACH})$. Acidic oxygen functionalities may enhance the TC adsorption onto activated carbons [30,35,36] and their presence will complicate the analysis of TC adsorption isotherms by metal-loaded carbons, therefore they were removed prior to the metal impregnation step. Different oxygen functionalities on the surface of carbon materials include carboxyl, anhydride, carbonyl, lactone, lactol, phenolic, quinone, and ether groups. Acidic oxygen groups consist of carboxyl, anhydride, lactone/lactol, and phenolic groups. Temperature programmed desorption studies 
indicated that carboxyl, lactone, and anhydride groups decompose below $\sim 650{ }^{\circ} \mathrm{C}$; and phenol, carbonyl, ether, and quinone groups decompose at $700-980{ }^{\circ} \mathrm{C}$ [41].

The Boehm titration method was used to quantify the concentration of different acidic oxygen groups of the ACFH sample. No measureable amounts of carboxylic and lactone/lactol groups were detected for this sample, while a low concentration of $0.0625 \mathrm{mmol} / \mathrm{g}$ for the phenolic groups was measured. These results indicated that the concentrations of surface acidic oxygen groups on the ACFH were negligible.

ACFH was first loaded with $\mathrm{Cu}\left(\mathrm{NO}_{3}\right)_{2} \cdot 3 \mathrm{H}_{2} \mathrm{O}$, then treated at 400,530 , or $800{ }^{\circ} \mathrm{C}$ to selectively load ACFH with $\mathrm{CuO}, \mathrm{Cu}_{2} \mathrm{O}$, or $\mathrm{Cu}$. ACH is also loaded with $\mathrm{Cu}_{2} \mathrm{O}$ in a similar manner. Heat treatment temperatures are selected based on the thermal decomposition data of hydrated copper nitrate. In a nitrogen atmosphere, $\mathrm{Cu}\left(\mathrm{NO}_{3}\right)_{2} \cdot 3 \mathrm{H}_{2} \mathrm{O}$ first melts at $116-152{ }^{\circ} \mathrm{C}$, converts to $\beta-\mathrm{Cu}_{2}(\mathrm{OH})_{3} \mathrm{NO}_{3}$ at 199-2 $17{ }^{\circ} \mathrm{C}$, and decomposes to $\mathrm{CuO}$ at $263-310{ }^{\circ} \mathrm{C}$ [42]. $\mathrm{CuO}$ decomposes at $>450{ }^{\circ} \mathrm{C}$ to $\mathrm{Cu}_{2} \mathrm{O}$ [43] and finally decomposes to metallic copper at higher temperatures. It is also reported that $\mathrm{Cu}_{2} \mathrm{O}$ reduces directly to $\mathrm{Cu}$ at $>525^{\circ} \mathrm{C}$ [44].

Similarly, ACFH samples were loaded with $\mathrm{Ni}\left(\mathrm{NO}_{3}\right)_{2} \cdot 6 \mathrm{H}_{2} \mathrm{O}$ and heat treated at $550{ }^{\circ} \mathrm{C}$ in nitrogen or $800{ }^{\circ} \mathrm{C}$ in hydrogen to selectively load the carbon with $\mathrm{NiO}$ or $\mathrm{Ni}$ species. $\mathrm{Ni}\left(\mathrm{NO}_{3}\right)_{2} \cdot 6 \mathrm{H}_{2} \mathrm{O}$ is reported to decompose to $\mathrm{NiO}$ at $>350{ }^{\circ} \mathrm{C}$ [43]. A high temperature $\left(800{ }^{\circ} \mathrm{C}\right)$ and a reductive atmosphere $\left(\mathrm{H}_{2}\right)$ were selected to ensure complete reduction of $\mathrm{NiO}$ to metallic nickel. XRD results are presented in the next section to show the selective impregnation of the adsorbents by desired metal species.

\subsubsection{Characterization of Loaded Copper and Nickel Species}

Total metal content of different samples impregnated with copper or nickel species were measured to ensure that all metals in the nitrate solutions were deposited on the samples. The measured total metal content of all samples was $\sim 10$ wt $\%$, close to the targeted $10 \%$ loading amount. However, samples were loaded with different types of copper or nickel species.

Carbon adsorbents were examined by x-ray diffraction analysis. The results are shown in Figure 1. XRD plots show noisy background patterns, as commonly observed for amorphous carbon materials [26] and clear peaks representing different crystalline copper or nickel species. XRD data were analyzed based on the ICDD database and PDF (powder diffraction file) numbers 48-1548 ( $\mathrm{ACFH}-\mathrm{Cu}^{2+}$ ), 34-1354 ( $\left.\mathrm{ACFH}-\mathrm{Cu}^{+}\right), 04-0836\left(\mathrm{ACFH}^{-\mathrm{Cu}^{0}}\right), 44-1159\left(\mathrm{ACFH}-\mathrm{Ni}^{2+}\right)$, and 04-0850 $\left(\mathrm{ACFH}-\mathrm{Ni}^{0}\right)$.

Diffraction peaks at $2 \theta=35.54^{\circ}, 38.7^{\circ}$ and $56.7^{\circ}$ show the presence of $\mathrm{CuO}$ in $\mathrm{ACFH}-\mathrm{Cu}^{2+}$, and peaks at $2 \theta=37^{\circ}, 42.6^{\circ}$ and $74.4^{\circ}$ indicate existence of $\mathrm{Cu}_{2} \mathrm{O}$ crystals in $\mathrm{ACFH}-\mathrm{Cu}^{+}$.

The $\mathrm{Cu}_{2} \mathrm{O}$ species were completely transformed into $\mathrm{Cu}^{0}$ at $800^{\circ} \mathrm{C}$, on ACFH-Cu , as evidenced by peaks at $2 \theta=43.2^{\circ}, 50.4^{\circ}$ and $74.1^{\circ} \cdot \mathrm{Cu}_{2} \mathrm{O}$ peaks, similar to those of $\mathrm{ACFH}-\mathrm{Cu}^{+}$were observed for $\mathrm{ACH}-\mathrm{Cu}^{+}$sample.

The peaks observed at $2 \theta=37.2^{\circ}, 62.8^{\circ}$ and $75.4^{\circ}$ are assigned to crystalline $\mathrm{NiO}$ particles for ACFH-Ni ${ }^{2+}$ sample. NiO particles were completely reduced to $\mathrm{Ni}$ as shown by diffraction peaks at $2 \theta=44.5^{\circ}$ and $84.2^{\circ}$ for $\mathrm{ACFH}-\mathrm{Ni}^{0}$ sample. 
Figure 1. XRD patterns of (a) copper- and (b) nickel-impregnated ACFH samples.

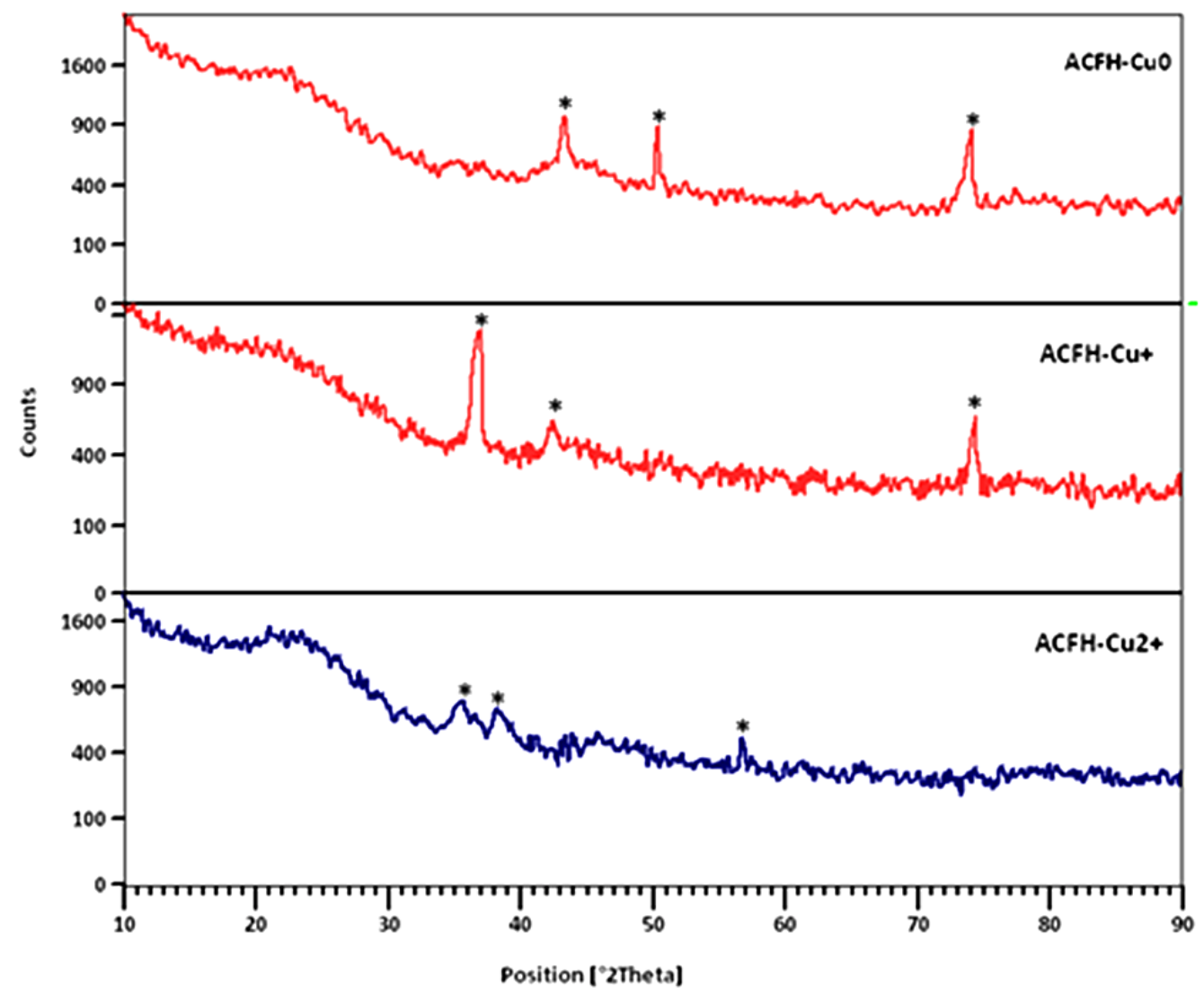

(a)

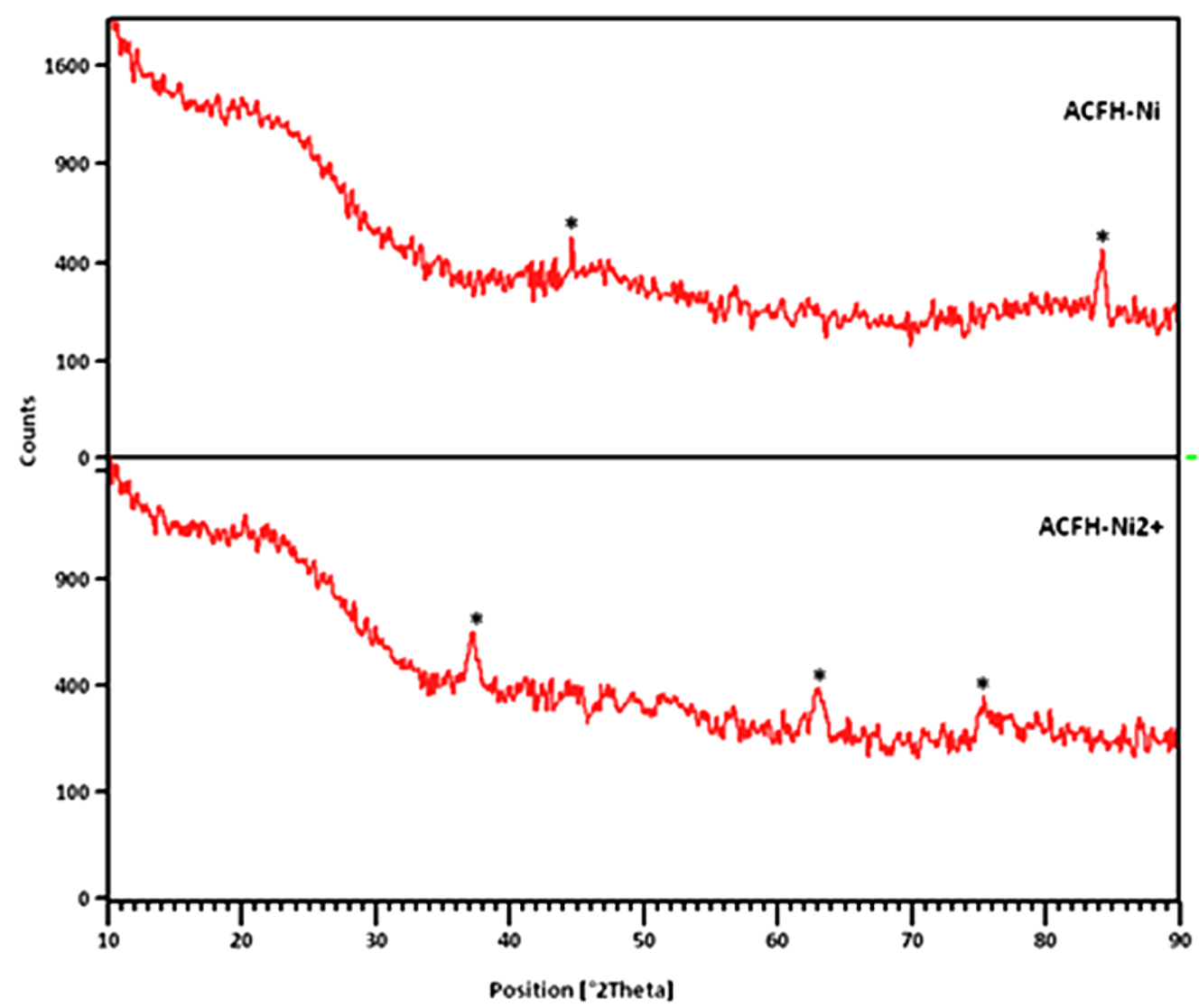

(b) 
$\mathrm{CO}$ chemisorption is used to characterize $\mathrm{Cu}_{2} \mathrm{O}$ dispersion on selected copper-impregnated samples. $\mathrm{CO}$ is chemisorbed only on $\mathrm{Cu}^{+}$sites and no irreversible $\mathrm{CO}$ adsorption occurs on $\mathrm{Cu}^{2+}$ or $\mathrm{Cu}^{0}$ sites [45]. $\mathrm{CO}$ adsorption isotherms of $\mathrm{ACFH}-\mathrm{Cu}^{+}, \mathrm{ACFH}-\mathrm{Cu}^{0}$, and $\mathrm{ACH}-\mathrm{Cu}^{+}$are shown in Figure 2. The first isotherm for each adsorbent represents both physi- and chemisorption uptakes. The second isotherm is the repeat of the first isotherm and shows only reversible physisorption data. The difference between the first and second isotherms represents the irreversible CO chemisorption. The intercept of the line fitted to the chemisorption data shows the chemisorbed coverage and is taken as the chemisorbed $\mathrm{CO}$ value onto the sample. Sample ACFH-Cu ${ }^{0}$ did not chemisorb CO. This result and $\mathrm{XRD}$ data indicate that $\mathrm{ACFH}-\mathrm{Cu}^{0}$ contains only metallic copper. The quantity of chemisorbed $\mathrm{CO}$ onto samples $\mathrm{ACFH}-\mathrm{Cu}^{+}$, and $\mathrm{ACH}-\mathrm{Cu}^{+}$were 0.0236 and $0.0117 \mathrm{mmol} / \mathrm{g}$ sample, respectively, that are equal to the quantity of dispersed $\mathrm{Cu}^{+}$on the sample surfaces. For comparison, all samples contained $10 \mathrm{wt} \%$ copper that is equal to $1.574 \mathrm{mmol} / \mathrm{g}$ sample. Low $\mathrm{Cu}^{+}$dispersion is due to the combinatory impacts of utilized metal precursor loading method and high calcination temperature.

Figure 2. CO adsorption isotherms of selected copper-impregnated samples.

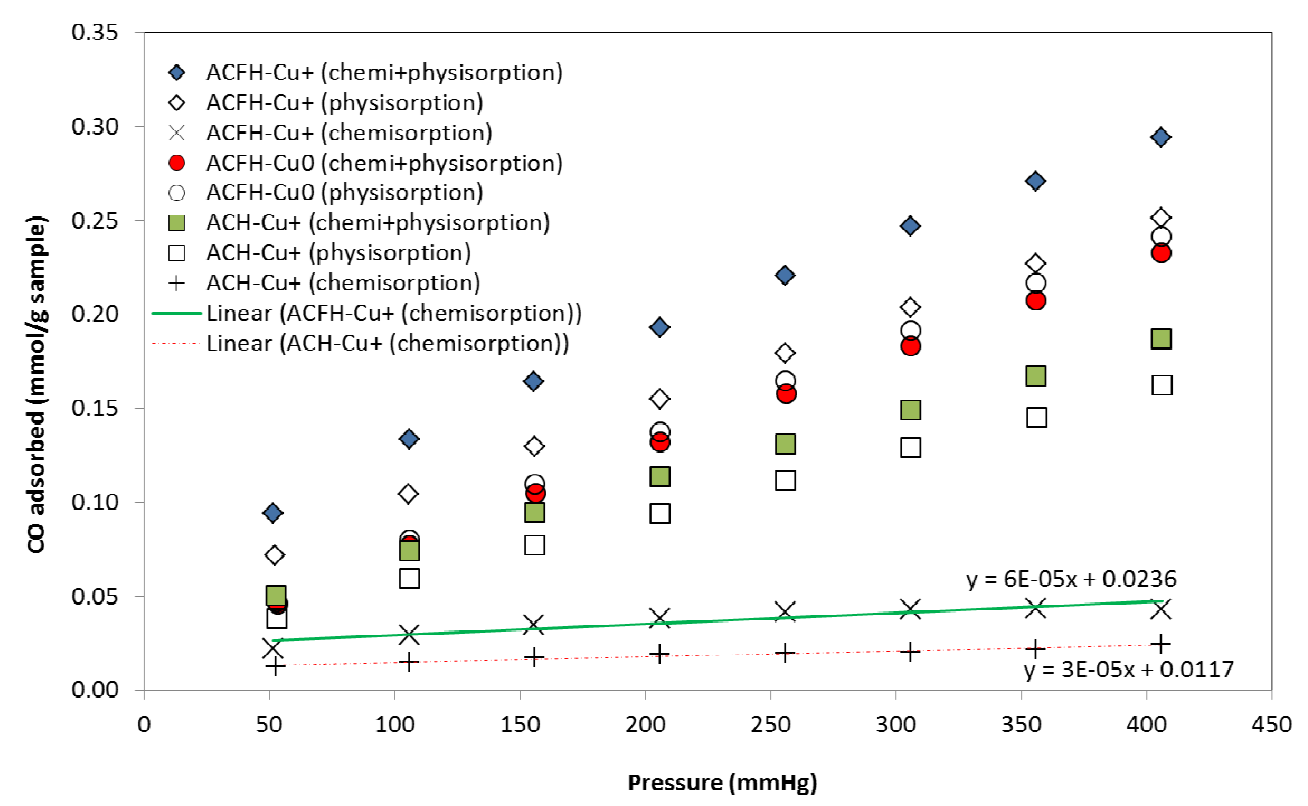

\subsubsection{Porosity Characterization}

Textural characteristics of original, hydrogen-treated, and metal-impregnated activated carbons are shown in Table 2. Surface area, micro- and mesoporosity, and pore volume distribution of carbons impregnated with different copper or nickel species are included to evaluate the impact of metal impregnation on the porosity of prepared adsorbents. Pore volume distribution in listed intervals is shown to compare ultra-micropore $(<0.7 \mathrm{~nm})$, super-micropore $(0.7-2 \mathrm{~nm})$, and meso + macropore $(>2 \mathrm{~nm})$ volumes of different carbons.

$\mathrm{ACF}$ is a microporous activated carbon fiber without any significant mesoporosity. High temperature hydrogen treatment slightly increases carbon surface area and micropore volume and has a minimal impact on the carbon pore volume distribution. These slight changes are due to the removal of surface oxygen functionalities that may have twofold impacts: first, widening the pore widths, and second, contributing to the weight loss of samples; thus increasing the weight-normalized surface area 
and pore volume values. All metal-impregnated samples, except $\mathrm{ACFH}-\mathrm{Cu}^{0}$ and $\mathrm{ACFH}-\mathrm{Ni}^{0}$, have surface area, porosity, and pore volume distribution values similar to those of ACFH. Increase in the surface area and porosity of $\mathrm{ACFH}-\mathrm{Cu}^{0}$ and $\mathrm{ACFH}-\mathrm{Ni}^{0}$ is most likely due to carbon catalytic gasification by metallic copper and nickel at $800{ }^{\circ} \mathrm{C}[46,47]$. Unlike other ACFH samples, ACFH-Ni ${ }^{0}$ has a considerable $(\sim 14 \%)$ mesoporosity that is created by pore widening of ACFH during the high temperature hydrogen treatment, due to catalytic gasification of carbon by hydrogen in the presence of zero-valent nickel [48].

Table 2. Surface area and porosity of adsorbents.

\begin{tabular}{|c|c|c|c|c|c|c|c|}
\hline \multirow{2}{*}{ Sample } & \multirow{2}{*}{$\begin{array}{l}S_{\text {BET }} \\
\mathrm{m}^{2} / g\end{array}$} & \multirow{2}{*}{$\begin{array}{l}V_{\text {total }} \\
\mathrm{cm}^{3} / \mathrm{g}\end{array}$} & \multirow{2}{*}{$\begin{array}{c}V_{\text {micro, }} \text { DR } \\
\mathbf{c m}^{3} / \mathbf{g}\end{array}$} & \multirow{2}{*}{$\begin{array}{c}V_{\text {meso+macro }} \\
\mathbf{c m}^{3} / \mathbf{g}\end{array}$} & \multicolumn{3}{|c|}{ DFT pore volume distribution, $\mathrm{cm}^{3} / \mathrm{g}(\%)$} \\
\hline & & & & & $<0.7 \mathrm{~nm}$ & $0.7-2 \mathrm{~nm}$ & $>\mathbf{2} \mathbf{n m}$ \\
\hline $\mathrm{ACF}$ & 979 & 0.378 & 0.376 & 0.002 & $0.205(62.7)$ & $0.122(37.3)$ & $0.000(0.0)$ \\
\hline $\mathrm{ACFH}$ & 1077 & 0.426 & 0.424 & 0.002 & $0.197(52.8)$ & $0.176(47.2)$ & $0.000(0.0)$ \\
\hline $\mathrm{ACFH}-\mathrm{Cu}^{+2}$ & 1090 & 0.433 & 0.429 & 0.004 & $0.186(50.8)$ & $0.180(49.2)$ & $0.000(0.0)$ \\
\hline $\mathrm{ACFH}-\mathrm{Cu}^{+}$ & 981 & 0.388 & 0.385 & 0.003 & $0.172(50.6)$ & $0.167(49.1)$ & $0.001(0.3)$ \\
\hline $\mathrm{ACFH}-\mathrm{Cu}^{0}$ & 1327 & 0.526 & 0.514 & 0.012 & $0.282(62.3)$ & $0.171(37.7)$ & $0.000(0.0)$ \\
\hline ACFH-Ni $i^{+2}$ & 1075 & 0.430 & 0.419 & 0.011 & $0.184(46.2)$ & $0.212(53.3)$ & $0.002(0.5)$ \\
\hline $\mathrm{ACFH}-\mathrm{Ni}^{0}$ & 1053 & 0.492 & 0.410 & 0.082 & $0.163(39.8)$ & $0.191(46.6)$ & $0.056(13.7)$ \\
\hline $\mathrm{AC}$ & 1365 & 0.894 & 0.495 & 0.399 & $0.100(15.0)$ & $0.227(34.0)$ & $0.341(51.0)$ \\
\hline $\mathrm{ACH}$ & 1341 & 0.805 & 0.511 & 0.294 & $0.078(11.8)$ & $0.262(39.8)$ & $0.319(48.4)$ \\
\hline $\mathrm{ACH}-\mathrm{Cu}^{+}$ & 1245 & 0.800 & 0.452 & 0.348 & $0.088(14.4)$ & $0.213(34.9)$ & $0.3090 .7)$ \\
\hline
\end{tabular}

$\mathrm{AC}$ is a mesoporous activated carbon that has a micropore volume comparable to the ACF but also contains a high mesopore volume. It should be noted that the ultra-micropore volume of $\mathrm{AC}$ is significantly lower than that of ACF. Hydrogen treatment and copper impregnation do not considerably change surface area and porosity of AC carbons.

An analysis of porosity data of original and metal-impregnated carbons indicate that the $10 \%$ metal impregnation did not have a high impact on the porosity of prepared adsorbents. No carbon pore plugging by impregnated metal species is observed for these samples.

\subsection{Adsorption of Thiophenic Compounds}

In agreement with the previous reports [12,38], our kinetics tests showed that equilibrium could be reached in $8 \mathrm{~h}$, when the samples were continuously stirred, so the equilibrium time was set to $8 \mathrm{~h}$ in all runs.

Adsorption isotherms of BT, DBT and 4, 6-DMDBT onto activated carbon fibers impregnated with different copper or nickel species are shown in Figures 3-5. The Langmuir-Freundlich (LF) equation is reported to be a suitable model for the adsorption of TC onto activated carbon [20], therefore, experimental adsorption data are fitted to the LF model and plotted to show the overall isotherm trends in these figures. Adsorption data of majority of adsorbents fitted well into the LF model with correlation coefficients greater than 0.94. Unlike ACFH isotherms, DBT isotherms of two mesoporous $\mathrm{ACH}$ and $\mathrm{ACH}-\mathrm{Cu}^{+}$carbons poorly fitted into the LF model with correlation coefficients of 0.81 and 0.86, respectively. Observed higher adsorption affinities of microporous ACFH carbons at low concentrations $(<50 \mathrm{mg} \mathrm{S} / \mathrm{L})$ is due to the DBT adsorption in high-energy ultra-micropores. ACFH 
isotherms are also similar to the standard type I isotherm. However, for mesoporous ACH carbons a linear trend for the isotherms is observed, suggesting a similar adsorption affinity over the tested concentration range. While the microporous carbons appear to reach their maximum TC capacities at equilibrium concentration of $\sim 200 \mathrm{mg} \mathrm{S} / \mathrm{L}$, two tested mesoporous carbons are expected to have much higher capacities at higher concentrations $(>>200 \mathrm{mg}$ S/L).In agreement with the previous reports $[14,16,19-21,49]$, our results show that copper or nickel impregnation improves the TC uptake onto activated carbon adsorbents. However, this study quantifies the importance of different individual metal species on the TC adsorption. A specific approach of this work is to subject the adsorbents (prior to the metal impregnation) to a high temperature hydrogen reduction to remove acidic oxygen functionalities that are suggested to increase TC adsorption onto activated carbons $[30,35,36]$ therefore the possible contribution of oxygen acidic groups can be excluded. All ACFH carbons have similar microporosity and comparable ultra- and super-microporosity (Section 3.1.2). Therefore, enhanced adsorption of TC is primarily attributed to the impact of specific loaded copper and nickel species.

A comparison of ACFH isotherms shows that metal impregnation could not increase the TC uptake more than $\sim 40 \%-53 \%$ (i.e., about $70 \%$ of the TC uptake by metal loaded carbons is due to the TC adsorption on the carbon surface and the remaining 30\% is due to the adsorption of TC on metal sites). All ACFH adsorbents have similar microporosities and should have similar physical dispersion interactions with TC. This confirms that adsorption of TC is primarily governed by dispersion interactions in carbon micropores (as suggested by other researchers [30]) but specific interactions between the loaded metal species and TC molecules further increase the TC uptake.

To investigate the impact of meso and macropores on TC adsorption, DBT isotherms of ACFH and $\mathrm{ACH}$ are compared and shown in Figure 3.ACH and ACFH total micropore volumes are comparable but ultra-micropore volume of ACFH is about 2.5 times higher than that of ACH as shown in Table 2. Furthermore, $\mathrm{ACH}$ has a considerable amount of mesoporosity. Results indicate that at low to medium equilibrium concentrations $(<150 \mathrm{mg} \mathrm{S} / \mathrm{L}$ ), DBT uptake of $\mathrm{ACH}$ is significantly lower than $\mathrm{ACFH}$, due to the smaller ultra-micropore volume of ACF than $\mathrm{ACFH}$. $\mathrm{Cu}_{2} \mathrm{O}$ impregnation only slightly improves the DBT uptake of the mesoporous carbon at high concentrations.

Although different metal-loaded ACFH samples had the same total metal content (i.e., $10 \mathrm{wt} \% \mathrm{Cu}$ or $\mathrm{Ni}$ ) depending on the type of impregnated metal species, they improved TC uptake differently. Among all copper-impregnated samples the $\mathrm{Cu}_{2} \mathrm{O}$-impregnated sample $\left(\mathrm{ACFH}-\mathrm{Cu}^{+}\right.$) showed the highest uptake for BT, DBT, and 4,6-DMDBT. Under the same experimental conditions, the DBT, 4,6-DMDBT and BT adsorption capacity of $\mathrm{Cu}_{2} \mathrm{O}$-impregnated $\mathrm{ACFH}$ is up to $40 \%, \sim 53 \%$ and $\sim 44 \%$, respectively higher than ACFH. The overall uptake trends for all three TC by copper-impregnated activated carbon fibers are as follows:

$$
\mathrm{ACFH}-\mathrm{Cu}^{+}>\mathrm{ACFH}-\mathrm{Cu}^{2+}>\mathrm{ACFH}-\mathrm{Cu}^{0}>\mathrm{ACFH}
$$

Suggesting the following order of affinity of copper species for TC adsorption:

$$
\mathrm{Cu}_{2} \mathrm{O}\left(\mathrm{Cu}^{+}\right)>\mathrm{CuO}\left(\mathrm{Cu}^{2+}\right)>\mathrm{Cu}\left(\mathrm{Cu}^{0}\right)
$$

For nickel-impregnated carbons, NiO-impregnated samples showed the highest uptake for all tested TC: 
This trend suggests a higher affinity of $\mathrm{NiO}\left(\mathrm{Ni}^{2+}\right)$ than $\mathrm{Ni}$ for $\mathrm{TC}$ adsorption.

Copper and nickel species interact with $\pi$-electrons of thiophene molecules. Sulfur and metal atoms also interact by $\eta^{1}-S$ and $S-\eta_{3}$ bonding [22]. It is reported that $\pi$-complexation bonds between $\mathrm{Cu}^{+}$ (or $\mathrm{Ni}^{2+}$ ) and sulfur ring is stronger than that with a benzene ring [50]. It is further hypothesized that $\mathrm{Cu}^{+}$or $\mathrm{Ni}^{2+}$ form stronger complexes than other oxidation states of copper or nickel [50].

Figure 3. Adsorption isotherms of DBT onto activated carbons impregnated with different copper and nickel species. Solid lines represent Langmuir-Freundlich fit of the data.

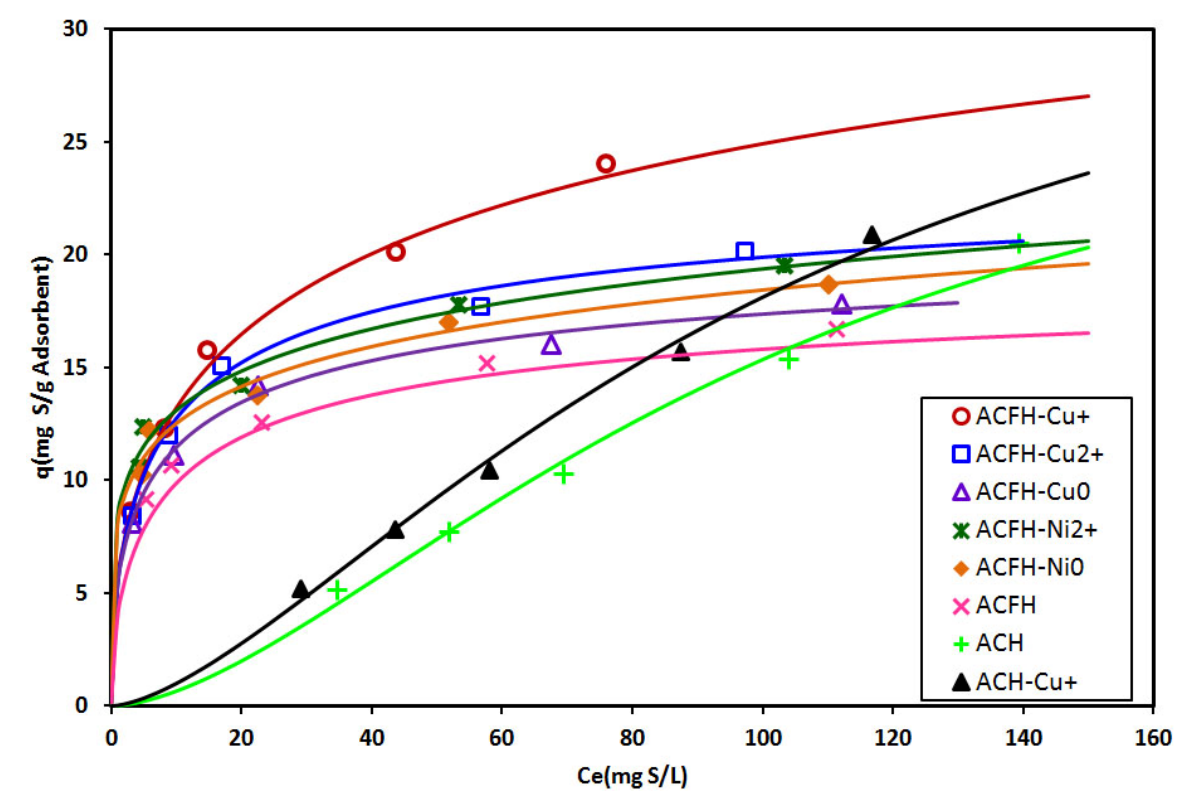

Figure 4. Adsorption isotherms of BT onto activated carbon fibers impregnated with different copper and nickel species. Solid lines represent Langmuir-Freundlich fit of the data.

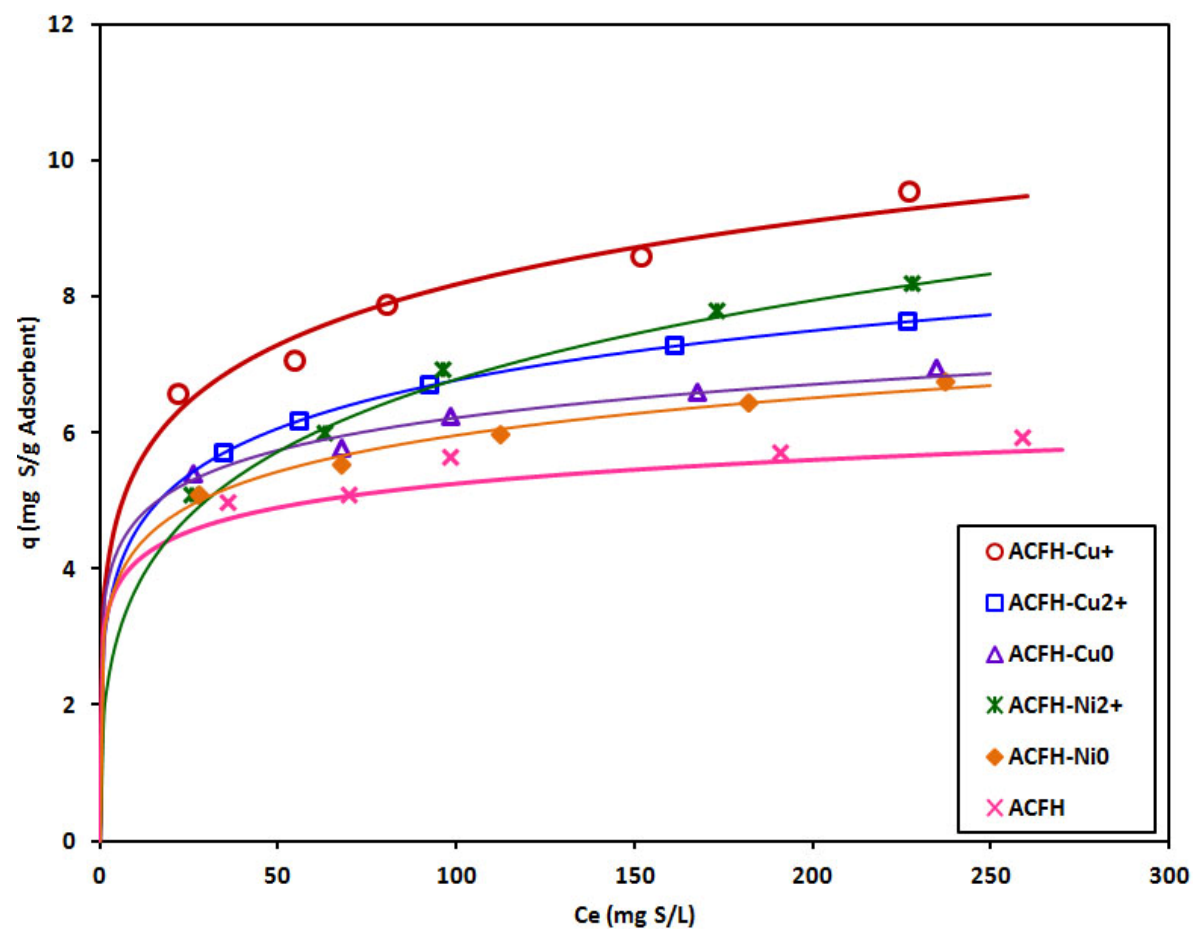


Figure 5. Adsorption isotherms of 4,6-DMDBT onto activated carbon fibers impregnated with different copper and nickel species. Solid lines represent Langmuir-Freundlich fit of the data.

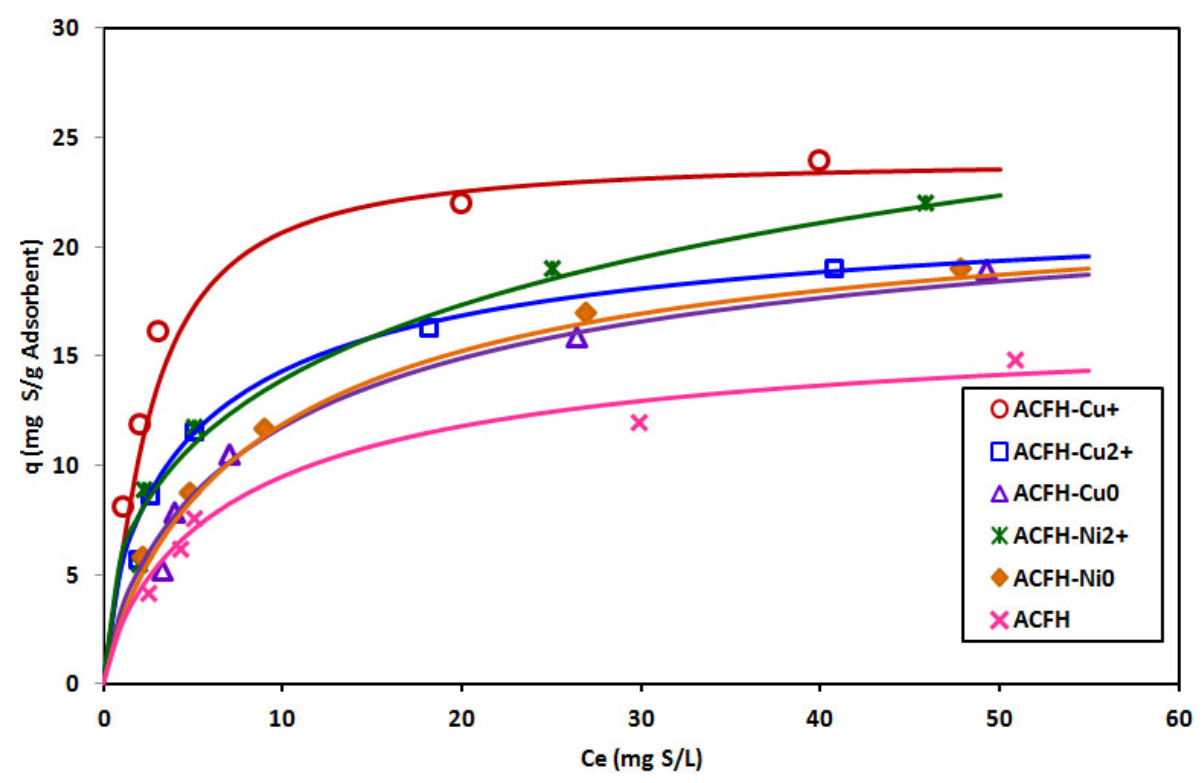

Better performance of ACF-Cu ${ }^{+}$compared to other adsorbents might be also explained based on the Lewis acid-base interactions of hard and soft acids and bases (HSAB) theory, as proposed for the reported enhanced adsorption of BT and DBT by $\mathrm{Ag}^{+}$-impregnated activated carbon [22]. This theory was made quantitative by assigning numbers representing "hardness" and "softness" to acids and bases by Parr and Pearson [51]. HSAP theory indicates that hard acids prefer hard bases and soft acids prefer soft bases [52]. Absolute hardness values of different copper/nickel oxidation states and thiophenic compounds are listed in Table $3 . \mathrm{Cu}^{+}$is a soft acid but other ions and atoms, $\mathrm{Ni}^{2+}, \mathrm{Cu}^{2+}, \mathrm{Ni}^{0}$ and $\mathrm{Cu}^{0}$ are neutral or borderline acids. Furthermore, In terms of Pearson hard-soft base classification, TCs are considered as soft bases. Therefore, the observed enhanced adsorption of TC by ACFH-Cu ${ }^{+}$can be explained by the enhanced acid-base interaction of DBT as a soft base with $\mathrm{Cu}^{+}$as a soft acid.

Table 3. Absolute hardness of copper/nickel oxidation states and thiophenic compounds based on Pearson classification.

\begin{tabular}{lcll}
\hline Compound & Absolute Hardness (eV) & Soft/Hard, Acid/Base & Reference \\
\hline $\mathrm{Cu}^{+}$ & 6.3 & Soft Acid & {$[51]$} \\
$\mathrm{Cu}^{2+}$ & 8.3 & Borderline Acid & {$[51]$} \\
$\mathrm{Cu}^{0}$ & 3.25 & Neutral & {$[51]$} \\
$\mathrm{Ni}^{2+}$ & 8.5 & Borderline Acid & {$[51]$} \\
$\mathrm{Ni}^{0}$ & 3.24 & Neutral & {$[51]$} \\
$\mathrm{BT}$ & 5.602 & Soft Base & {$[22]$} \\
$\mathrm{DBT}$ & 5.267 & Soft Base & {$[22]$} \\
\hline
\end{tabular}

Sulfur adsorption uptake of the majority of adsorbents follows the order of: 4,6-DMDBT $>$ DBT $>$ BT as shown in Figures 3-5. The same order is observed if the sulfur-based uptakes are converted to TC-based uptakes and is consistent with the reported trends by other investigators [26,53]. The 
molecular geometries of three tested compounds are shown in Figure 6. All three TC molecules have planar geometries and can orient themselves to enter the carbon slit-shaped ultra-micropores. 4,6-DMDBT has a thickness of $4.2 \AA$, compared to the $3.6 \AA$ thickness of DBT and BT, that is closer to the width of carbon ultra-micropores $(<7 \AA)$. Therefore, there is a higher overlapping adsorption potential effect for 4,6-DMDBT than DBT and BT.4,6-DMDBT and DBT have also larger molecular cross sectional areas (than BT), further enhancing their dispersion and $\pi-\pi$ interactions with the graphene sheets.

Figure 6. Molecular dimensions and structures of (a) BT; (b) DBT; and (c) 4,6-DMBT calculated from the DFT model in the Gaussian 98 software.

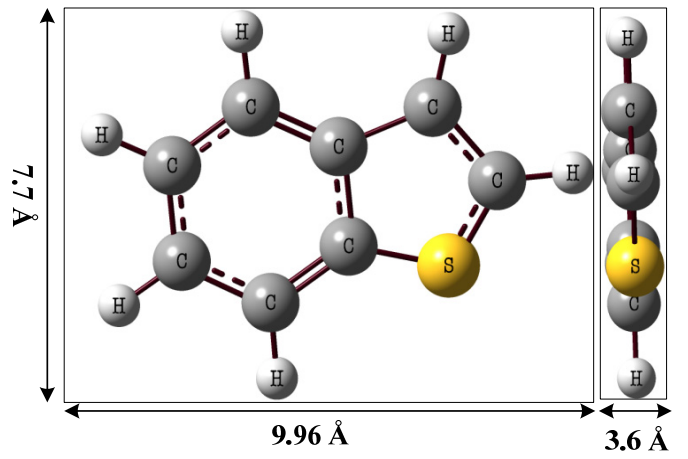

(a)

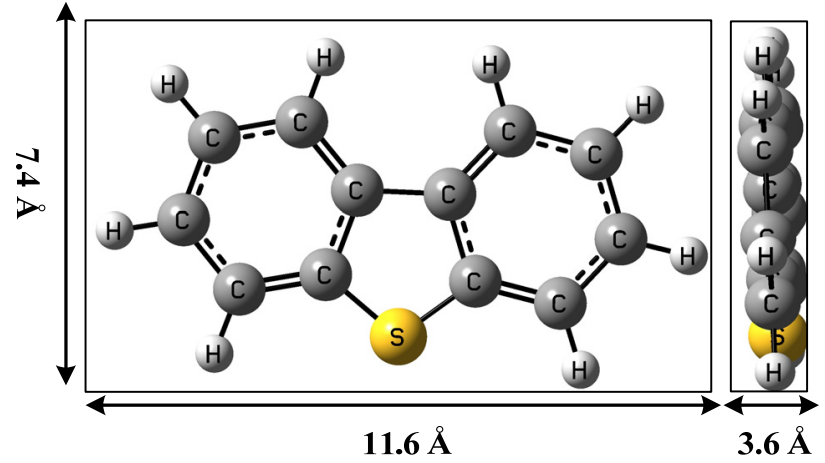

(b)

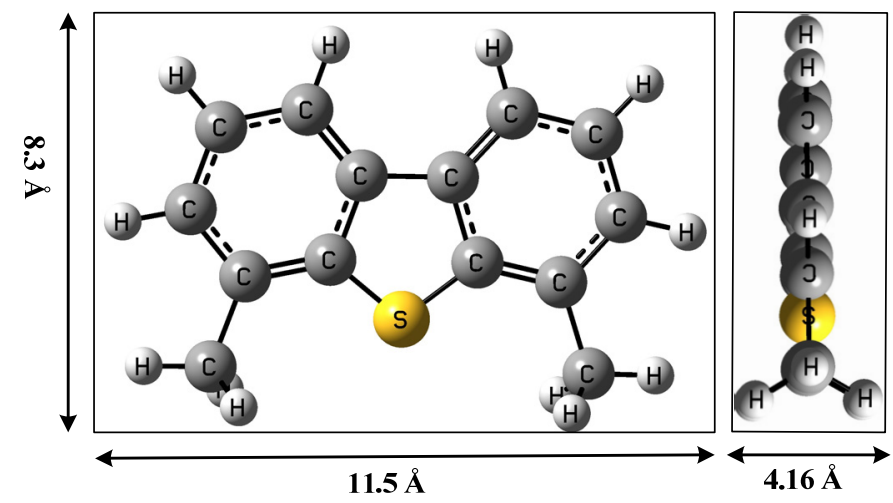

(c)

Higher adsorption of 4,6-DMDBT (than DBT and BT) by $\mathrm{ACFH}-\mathrm{Cu}^{+}$is also due to specific interactions. An obvious molecular difference of 4,6-DMDBT with DBT and BT is the existence of two methyl groups. These electron donating groups increase the electron density of aromatic and sulfur rings in the 4,6-DMDBT molecule, thus enhancing the $\pi$-complexation interaction with $\mathrm{Cu}^{+}\left(\mathrm{or} \mathrm{Ni}^{2+}\right)$.

To further assess the mechanism of TC adsorption on $\mathrm{Cu}^{+}$sites, the monolayer adsorption capacity of exposed $\mathrm{Cu}^{+}$sites on the $\mathrm{ACFH}-\mathrm{Cu}^{+}$sample is estimated and compared with that calculated from the experimental TC uptake data. These results are shown in Table 4.Exposed $\mathrm{Cu}^{+}$sites are quantified by $\mathrm{CO}$ chemisorption analysis, as previously discussed. Each $\mathrm{Cu}^{+}$surface site may interact with one sulfur atom from the TC compound, resulting in a maximum monolayer coverage of $0.755 \mathrm{mg} \mathrm{S} / \mathrm{g}$ ACFH-Cu${ }^{+}$. Observed enhancement of $\mathrm{TC}$ uptake by $\mathrm{Cu}^{+}$loading onto ACFH at an arbitrary equilibrium concentration of $33 \mathrm{mg} \mathrm{S} / \mathrm{L}$ is $2-10$ times of the theoretical $\mathrm{Cu}^{+}$monolayer coverage. This analysis suggests two possibilities. First, $\mathrm{Cu}^{+}$sites act as the centers to accumulate TC molecules on 
the surface, and second, TC molecules might catalytically decompose/convert to other compounds on the $\mathrm{Cu}^{+}$sites, then TC reaction products are released into solution and adsorbed on the carbon surface. The second possibility appears to be more likely therefore; DBT adsorption solutions at equilibrium were analyzed with GC and no other compounds than the original DBT compounds were detected in the solutions, although no other solutes than DBT were detected in the solution; it is possible that the $\mathrm{Cu}$-catalyzed products are adsorbed on the surface. The detection of these species on the carbon surface needs to be further investigated in future studies.

Table 4. A comparison of estimated monolayer adsorption capacities of $\mathrm{TC}$ on $\mathrm{Cu}+$ sites and experimental TC uptakes.

\begin{tabular}{|c|c|c|c|c|}
\hline \multirow{2}{*}{$\mathbf{T C}$} & \multicolumn{3}{|c|}{ TC uptake * } & \multirow{2}{*}{$\begin{array}{c}\text { Monolayer capacity of exposed } \\
\mathrm{Cu}^{+} \text {sites on ACFH-Cu}{ }^{+* *} \\
\text { mg S/ g sample }\end{array}$} \\
\hline & $\begin{array}{l}\mathrm{mg} \mathrm{S} / \mathrm{g} \\
\mathrm{ACFH}\end{array}$ & $\begin{array}{c}\mathrm{mg} \mathrm{S} / \mathrm{g} \\
\mathrm{ACFH}-\mathrm{Cu}^{+}\end{array}$ & $\begin{array}{c}\text { Difference } * * * \\
\left(\mathrm{mg} \mathrm{S} / \mathrm{g} \mathrm{ACFH}-\mathrm{Cu}^{+}\right)\end{array}$ & \\
\hline BT & 5.0 & 6.8 & 1.8 & 0.755 \\
\hline $\mathrm{DBT}$ & 14.0 & 19.0 & 5.0 & 0.755 \\
\hline 4,6-DMBT & 15.5 & 23.5 & 8.0 & 0.755 \\
\hline
\end{tabular}

\section{Summary and Conclusions}

This paper investigated the impact of selective loading of different copper and nickel species on activated carbons for adsorption of benzothiophene (BT), dibenzothiophene (DBT), and 4,6-dimethyl-dibenzothiophene (4,6-DMDBT) from single-solute model fuel solutions. Summary and main conclusions of this work are listed below:

i. Copper- or nickel-loaded adsorbents were prepared from hydrogen-treated activated carbon samples. Prepared adsorbents had the same total metal contents butwere selectively loaded with $\mathrm{Ni}, \mathrm{NiO}, \mathrm{Cu}, \mathrm{Cu}_{2} \mathrm{O}$, or $\mathrm{CuO}$ species. Metal-loaded samples and their precursors had similar porosities.

ii. Copper or nickel loading increased the uptake of thiophenic compounds (TC) from the model fuel up to $40 \%-53 \%$ (i.e., about $70 \%$ of the TC uptake by metal loaded carbons is due to TC adsorption on the carbon surface and the remaining $30 \%$ is due to the adsorption of TC on metal sites). This confirms that adsorption of TC is primarily governed by dispersion interactions in carbon micropores, but specific interactions between the loaded metal species and TC molecules further increase the TC uptake. Adsorbents loaded with $\mathrm{Cu}_{2} \mathrm{O}$ or $\mathrm{NiO}$ species showed the highest uptakes, due to more specific interactions, including $\pi$-complexation and acid-base interactions, between $\mathrm{Cu}^{+}$or $\mathrm{Ni}^{2+}$ and TC molecules.

iii. A comparison of estimated maximum monolayer capacity of exposed $\mathrm{Cu}+$ sites for $\mathrm{TC}$ adsorption with the experimental uptake data suggested two possibilities: (1) catalytic conversion of TC molecules to other compounds on the $\mathrm{Cu}+$ sites, followed by adsorption of reaction products onto the carbon surface; and (2) multilayer accumulation of TC molecules on the $\mathrm{Cu}+$ sites. The first possibility appears to be more likely. 
iv. TC adsorption uptake of the majority of adsorbents followed the order of: 4,6-DMDBT > DBT $>$ BT due to higher intensity of specific and non-specific interactions of larger TC molecules with adsorbents.

\section{References}

1. Song, C.; Ma, X. New design approaches to ultra-clean diesel fuels by deep desulfurization and deep dearomatization. Appl. Catal. B Environ. 2003, 41, 207-238.

2. Houalla, M.; Broderick, D.H.; Sapre, A.V.; Nag, N.K.; de Beer, V.H.J.; Gates, B.C.; Kwart, H. Hydrodesulfurization of methyl-substituted dibenzothiophenes catalyzed by sulfided $\mathrm{Co}-\mathrm{Mo} / \gamma-\mathrm{Al}_{2} \mathrm{O}_{3}$. J. Catal. 1980, 61, 523-527.

3. Ma, X.; Sakanishi, K.; Mochida, I. Hydrodesulfurization reactivities of various sulfur compounds in diesel fuel. Ind. Eng. Chem. Res. 1994, 33, 218-222.

4. Ma, X.; Sakanishi, K.; Isoda, T.; Mochida, I. Hydrodesulfurization reactivities of narrow-cut fractions in a gas oil. Ind. Eng. Chem. Res. 1995, 34, 748-754.

5. Cristol, S.; Paul, J.F.; Payen, E.; Bougeard, D.; Hutschka, F.; Clémendot, S. DBT derivatives adsorption over molybdenum sulfide catalysts: A theoretical study. J. Catal. 2004, 224, 138-147.

6. Gislason, J. Pillips sulfur removal process nears commercialization. Oil Gas J. 2001, 99, 72-76.

7. Kim, J.H.; Ma, X.; Zhou, A.; Song, C. Ultra-deep desulfurization and denitrogenation of diesel fuel by selective adsorption over three different adsorbents: A study on adsorptive selectivity and mechanism. Catal. Today 2006, 111, 74-83.

8. Jiang, M.; Ng, F.T.T. Adsorption of benzothiophene on $\mathrm{Y}$ zeolites investigated by infrared spectroscopy and flow calorimetry. Catal. Today 2006, 116,530-536.

9. Jiang, M.; Ng, F.T.T.; Rahman, A.; Patel, V. Flow calorimetric and thermal gravimetric study of adsorption of thiophenic sulfur compounds on NaY zeolite. Thermochim. Acta 2005, 434, 27-36.

10. Ng, F.T.T.; Rahman, A.; Ohasi, T.; Jiang, M. A study of the adsorption of thiophenic sulfur compounds using flow calorimetry. Appl. Catal. B Environ. 2005, 56, 127-136.

11. Meng, C.; Fang, Y.; Jin, L.; Hu, H. Deep desulfurization of model gasoline by selective adsorption on Ag+/Al-MSU-S. Catal. Today 2010, 149, 138-142.

12. Wang, J.; Xu, F.; Xie, W.; Mei, Z.; Zhang, Q.; Cai, J.; Cai, W. The enhanced adsorption of dibenzothiophene onto cerium/nickel-exchanged zeolite Y. J. Hazard. Mater. 2009, 163, 538-543.

13. Thomas, J.K.; Gunda, K.; Rehbein, P.; Ng, F.T.T. Flow calorimetry and adsorption study of dibenzothiophene, quinoline and naphthalene over modified Y zeolites. App. Catal. B Environ. 2010, 94, 225-233.

14. Ma, X.; Sprague, M.; Song, C. Deep desulfurization of gasoline by selective adsorption over nickel-based adsorbent for fuel cell applications. Ind. Eng. Chem. Res. 2005, 44, 5768-5775.

15. Rheinberg, O.V.; Lucka, K.; Köhne, H.; Schade, T.; Andersson, J.T. Selective removal of sulphur in liquid fuels for fuel cell applications. Fuel 2008, 87, 2988-2996.

16. Park, J.G.; Ko, C.H.; Yi, K.B.; Park, J.H.; Han, S.S.; Cho, S.H.; Kim, J.N. Reactive adsorption of sulfur compounds in diesel on nickel supported on mesoporous silica. Appl. Catal. B Environ. 2008, 81, 244-250. 
17. Ma, X.; Sun, L.; Song, C. A new approach to deep desulfurization of gasoline,diesel fuel and jet fuel by selective adsorption for ultra-clean fuels and for fuel cell applications. Catal. Today 2002, 77, 107-116.

18. Komarneni, M.; Kadossov, E.; Justin, J.; Lu, M.; Burghaus, U. Adsorption of thiophene on silica-supported Mo clusters. Surf. Sci. 2010, 604, 1221-1229.

19. Jayne, D.; Zhang, Y.; Haji, S.; Erkey, C. Dynamics of removal of organosulfur compounds from diesel by adsorption on carbon aerogels for fuel cell applications. Int. J. Hydrogen Energy 2005, 30, 1287-1293.

20. Ania, C.O.; Bandosz, T.J. Metal-loaded polystyrene-based activated carbons as dibenzothiophene removal media via reactive adsorption. Carbon 2006, 44, 2404-2412.

21. Yu, M.; Li, Z.; Xia, Q.; Xi, H.; Wang, H. Desorption activation energy of dibenzothiophene on the activated carbons modified by different metal salt solutions. Chem. Eng. J. 2007, 132, 233-239.

22. Xiao, J.; Li, Z.; Liu, B.; Xia, Q.; Yu, M. Adsorption of benzothiophene and dibenzothiophene on ion-impregnated activated carbons and ion-exchanged $\mathrm{Y}$ zeolites. Energy Fuels 2008, 22, 3858-3863.

23. Seredych, M.; Bandosz, T.J. Selective adsorption of dibenzothiophenes on activated carbons with Ag, Co, and Ni species deposited on their surfaces. Energy Fuels 2009, 23, 3737-3744.

24. Hernandez, S.P.; Fino, D.; Russo, N. High performance sorbents for diesel oil desulfurization. Chem. Eng. Sci. 2010, 65, 603-609.

25. Xiao, J.; Bian, G.; Zhang, W.; Li, Z. Adsorption of dibenzothiophene on $\mathrm{Ag} / \mathrm{Cu} / \mathrm{Fe}$-supported activated carbons prepared by ultrasonic-assisted impregnation. J. Chem. Eng. Data 2010, 55, 5818-5823.

26. Seredych, M.; Bandosz, T.J. Adsorption of dibenzothiophenes on activated carbons with copper and iron deposited on their surfaces. Fuel Process. Technol. 2010, 91, 693-701.

27. Zhou, A.; Ma, X.; Song, C. Effects of oxidative modification of carbon surface on the adsorption of sulfur compounds in diesel fuel. Appl. Catal. B Environ. 2009, 87, 190-199.

28. Ferraz, M.C.M.A.; Monteiro, J.L.C. Structure of impregnated active carbons produced with almond shells influence of impregnation methodology. Fuel 2000, 79, 645-650

29. Seredych, M.; Bandosz, T.J. Adsorption of dibenzothiophenes on nanoporous carbons: Identification of specific adsorption sites governing capacity and selectivity. Energy Fuels 2010, 24, 3352-3360.

30. Seredych, M.; Bandosz, T.J. Investigation of the enhancing effects of sulfur and/or oxygen functional groups of nanoporous carbons on adsorption of dibenzothiophenes. Carbon 2011, 49, 1216-1224.

31. Ania, C.O.; Parra, J.B.; Arenillas, A.; Rubiera, F.; Bandosz, T.J.; Pis, J.J. On the mechanism of reactive adsorption of dibenzothiophene on organic waste derived carbons. Appl. Surf. Sci. 2007, 253, 5899-5903.

32. Farag, H. Selective adsorption of refractory sulfur species on active carbons and carbon based CoMo catalyst.J. Colloid. Interf. Sci. 2007, 307, 1-8.

33. Vilarrasa-García, E.; Infantes-Molina, A.; Moreno-Tost, R.M.; Rodríguez-Castellón, E.; Jiménez-López, A.; Cavalcante, C.L.; Azevedo, D.C.S. Thiophene adsorption on microporous activated carbons impregnated with $\mathrm{PdCl}_{2}$. Energy Fuels 2010, 24, 3436-3442. 
34. Rodríguez-Reinoso, F. The role of carbon materials in heterogeneous catalysis. Carbon 1998, 36, 159-175.

35. Deliyanni, E.; Seredych, M.; Bandosz, T.J. Interactions of 4,6-Dimethyldibenzothiophene with the surface of activated carbons. Langmuir 2009, 25, 9302-9312.

36. Seredych, M.; Lison, J.; Jans, U.; Bandosz, T.J. Textural and chemical factors affecting adsorption capacity of activated carbon in highly efficient desulfurization of diesel fuel. Carbon 2009, 47, 2491-2500.

37. Hu, Z.; Srinivasan, M.P.; Ni, P. Novel activation process for preparing highly microporous and mesoporous activated carbons. Carbon 2001, 39, 877-886.

38. Alhamed, Y.A.; Bamufleh, H.S. Sulfur removal from model diesel fuel using granular activated carbon from dates' stones activated by $\mathrm{ZnCl}_{2}$. Fuel 2009, 88, 87-94.

39. Jia, Y.F.; Thomas, K.M. Adsorption of Cadmium Ions on Oxygen Surface Sites in Activated Carbon. Langmuir 2000, 16, 1114-1122.

40. De Souza, W.F.; Guimaraẽs, I.R.; Guerreiro, M.C.; Oliveira, L.C.A. Catalytic oxidation of sulfur and nitrogen compounds from diesel fuel. Appl. Catal. A Gen. 2009, 360, 205-209.

41. Figueiredo, J.L.; Pereira, M.F.R.; Freitas, M.M.A.; Órfaõ, J.J.M. Modification of the surface chemistry of activated carbons. Carbon 1999, 37, 1379-1389.

42. Morozov, I.V.; Znamenkov, K.O.; Korenev, Y.M.; Shlyakhtin, O.A. Thermal decomposition of $\mathrm{Cu}\left(\mathrm{NO}_{3}\right)_{2} \cdot 3 \mathrm{H}_{2} \mathrm{O}$ at reduced pressures. Thermochim. Acta 2003, 403, 173-179.

43. Mu, J.; Perlmutter, D.O. Thermal decomposition of metal nitrates and their hydrates. Thermochim. Acta 1982, 56, 253-260.

44. Firmansyah, D.A.; Kim, T.; Kim, S.; Sullivan, K.; Zachariah, M.R.; Lee, D. Crystalline phase reduction of cuprous oxide $(\mathrm{Cu} 2 \mathrm{O})$ nano particles accompanied by a morphology change during ethanol-assisted spray pyrolysis. Langmuir 2009, 25, 7063-7071.

45. Kim, M.H.; Ebner, J.R.; Friedman, R.M.; Vannice, M.A. Determination of metal dispersion and surface composition in supported Cu-Pt catalysts. J. Catal. 2002, 208, 381-392.

46. Mckee, D.W. Chemistry and Physics of Carbon; Marcel Dekker: New York, NY, USA, 1981; Volume 16, pp. 2-112.

47. Gao, X.; Liu, S.; Zhang, Y.; Luo, Z.; Cen, K. Physicochemical properties of metal-doped activated carbons and relationship with their performance in the removal of $\mathrm{SO}_{2}$ and $\mathrm{NO}$. J. Hazard. Mater. 2011, 188, 58-66.

48. Figueiredo, J.L.; Trimm, D.L. Gasification of carbon deposits on nickel catalysts. J. Catal. 1975, $40,154-159$.

49. Hernández-Maldonado, A.J.; Qi, G.; Yang, R.T. Desulfurization of commercial fuels by pi-complexation: Monolayer $\mathrm{CuCl} /$ gama- $\mathrm{Al}_{2} \mathrm{O}_{3}$. Appl. Catal. B Environ. 2005, 61, 212-218.

50. Hernández-Maldonado, A.J.; Yang, R.T. Desulfurization of transportation fuels by adsorption. Catal. Rev. 2004, 46, 111-150.

51. Parr, R.G.; Pearson, R.G. Absolute Hardness: Companion Parameter to Absolute Electronegativity. J. Am. Chem. Soc. 1983, 105, 7512-7516.

52. Pearson, R.G. Hard and soft acids and bases, HSAB, Part I:Fundamental principl. J. Chem. Educ. 1968, 45, 581-587. 
53. Fallah, R.N.; Azizian, S. Removal of thiophenic compounds from liquid fuel by different modified activated carbon cloths. Fuel Process. Technol. 2012, 93, 45-52.

(C) 2012 by the authors; licensee MDPI, Basel, Switzerland. This article is an open access article distributed under the terms and conditions of the Creative Commons Attribution license (http://creativecommons.org/licenses/by/3.0/). 